\title{
Injunctions Against Occupational Hazards: The Right to Work Under Safe Conditions*
}

\author{
Alfred W. Blumrosen ${ }^{\dagger} \quad$ Donald MI. Ackermant ${ }^{\dagger}$ \\ Julie Kligermantt \\ Peter VanSchaick tit $^{\dagger} \dagger$ \\ Kevin D. Sheehyttiti
}

In enacting the Occupational Safety and Health Act in 1970, Congress articulated a policy of prevention of occupational hazards. Congress did not, however, provide for private actions by employees to enjoin unsafe working conditions. The authors of this Article argue that such actions are neither precluded by OSHA nor prohibited by preexisting federal law and thus may be brought in state court under traditional principles of equity.

Until recently, the law of worker safety focused on compensation for work-connected injuries. ${ }^{1}$ In 1970, however, Congress enacted the Occupational Safety and Health Act (OSHA) and thereby placed new emphasis on the prevention of occupational hazards. ${ }^{2}$ The implementation of this policy was entrusted to federal and state administrative

* This Article was initially developed in a seminar on the Administrative Process, conducted at Rutgers Law School in the spring of 1974. Mr. Kevin Sheehy contribnted to the development of the concepts during the seminar. The other authors continued the development of the paper in a research seminar in 1974-75. The authors wish to acknowledge Craig Livingstone, Esq., of the New Jersey Bar, and Jerome B. Gordon, who participated in the seminar and contributed to the concepts discussed in this Article.

+ A.B. 1950, J.D. 1953, University of Michigan; Professor of Law, Rutgers, The State University of New Jersey.

ti A.B. 1971, Rutgers College, New Brunswick, N.J.; J.D. 1975, Rutgers Law School, Newark, N.J.

itf A.B. 1970, Oberlin College; J.D. 1975, Rutgers Law School, Newark, N.J.

tit' B.A. 1971, State University of New York; J.D. 1975, Rutgers Law School, Newark, N.J.

tititi A.B. 1971, Rutgers College, New Brunswick, N.J.; J.D. 1974, Rutgers Law School, Newark, N.J.

1. See generally NATional Commission on State Workmen's COMPENSation LAWs, Historical Development of Workmen's Compensation Laws, in COMPENDIUM oN WORKMEN's COMPENSATION 11 (1973) [hereinafter cited as The COMPENDIUM].

2. Occupational Safety and Health Act of 1970, 29 U.S.C. $\$ 651-78$ (1970) [heremafter cited as OSHA]. The iminediate precursor of this development was the Federal Coal Mine Health and Safety Act of 1969, 30 U.S.C. $\$ \S 801-960$ (1970). See generally National Realty \& Constr. Co. v. Occupational Safety \& Health Review 
agencies, which have thus far been ineffective. ${ }^{3}$ Under these circumstances, private actions by employees to enjoin unsafe conditions are both necessary and appropriate to vindicate the national policy that occupational liazards be prevented. This Article examines whether such actions may be maintained, either on the basis of OSHA itself or under principles of state law. Although OSHA does not create a federal cause of action by which a worker may enforce its provisions against an employer, neither does it foreclose private actions under state law. Such actions will lie under the traditional principles of equity and are consonant with current concepts of legal regulation of industrial relations.

\section{I}

HISTORICAL BACKGROUND

\section{A. The Common Law and Workmen's Compensation}

The common law rules concerning worker safety evolved in the 19 th century out of neghigence actions for danages by employee against employer. These tort actions were superseded in the 20 th century by workmen's coinpensation laws, which focused on compensation rather than prevention. ${ }^{4}$ Although the risk of financial liability under the common law and under workmen's compensation may have been intended to encourage employers to provide safe working conditions, the availability of the defenses of assumption of risk, contributory negligence and fellow servant ${ }^{5}$ largely negated any financial incentive to do so. Similarly, the requirement that employers insure against liability through workmen's compensation programs enabled thein to decide on calculable fiscal grounds whether to run certain risks or change the operations to provide a measure of employee safety. Indeed, the efforts of insurance compamies to encourage employer safety programs through pricing policies and affirmative action programs have been only marginally effective. ${ }^{6}$

Comm'n, 489 F.2d 1257 (D.C. Cir. 1973); Miller, The Occupational Safety and Health Act of 1970 and the Law of Torts, 38 LAW \& CONTEMP. PROB. 612 (1974).

3. See discussion in Part IV(A) infra.

4. See The Compendium, supra note 1 , at 14-18.

5. W. PROSSER, LAW OF TORTS $\S 80$, at 526-27 (4th ed. 1971) [hereinafter cited as Prosser].

6. "Merit rating" is the name given to lowering premiums of firms with safer work records. Small firms, however, are not eligible for "merit rating"; their small size reduces the reliability of their experience statistics. See THE COMPENDIUM, supra note 1 , at 289.

Empirical studies have shown neither a substantial connection between merit rating and prevention in most states, nor an abrupt clrange in injury rates after workmeu's coinpensation statutes were passd. See H. SOMERS \& A. SOMERS, Workmen's COMPENSATION 228-30 (1954); Berkowitz, Aspects of the Economics of Workmen's Compensa- 
Both the common law and workmen's compensation laws place all or part of the risk of occupational injury on the einployee. Under the common law, if it is established that an injured worker knew or should have known of an occupational hazard he or she recovers nothing. Under workmen's compensation, the worker still bears a proportion of the loss. ${ }^{7}$ Neither the common law nor workmen's compensation entitles a worker to have the conditions of work made safe and healthful. Rather, this latter principle first appeared in employers' liability acts and in the interpretation of some state safety legislation. ${ }^{8}$ Although initially limited in application, these statutes and decisions are today important because they were the first to articulate the right to work under safe conditions.

In the late 1960 's, inspired by an increase both in accident rates ${ }^{9}$ and in concern for the humanization of the workplace, ${ }^{10}$ the revulsion against the law's allocation of risk of industrial injury led to federal legislation. First in the field of mine safety, and then in the general area of occupational safety and health, Congress announced a new national policy.11 Each employer:

(1) shall furnish to each of his employees cmployment and a place of employment which are free from recognized hazards that are causing or are likely to cause death or serious physical harm to his employees;

(2) shall comply with occupational safety and health standards promulgated under this Act. ${ }^{12}$

As a result of this new policy, in addition to the right to be compensated for injuries incurred, the worker has a right to be free of dangers in the workplace. The philosophy of OSHA represents as significant a shift in the law as the shift from common law negligence to strict hability under

tion, in National Institutes on Rehabulttation and Health Services, Report op THE NATHONAI WORKSHOP ON REHABILITATION AND WORKMEN'S COMPENSATION 13, 24 (1971).

Moreover, since benefits under workmen's compensation acts do not cover the whole cost of injury or illness to the worker, either in scope of coverage or in level of benefits, the premiums do not reflect the full cost of accidents or illness.

7. Prosser, supra note $5, \S 80$, at 530-32.

8. F. HARPER \& F. JAMES, THE LAW OF TORIS $\$ 22.9$ (1956) [hereinafter cited as HARPER \& JAMES].

9. H.R. ReP. No. 1291, 91st Cong., 2d Sess. 14-16 (1970); S. Rep. No. 1282, 91st Cong., 2d Sess. 2-5 (1970).

10. Several pieces of legisiation reflect this increased concern for the humanization of the workplace. Age Discrimination in Employment Act of 1967, 29 U.S.C. $\$ \S 621$ 34 (1970); Equal Employment Opportunity Act, 42 U.S.C. 32000 (e) (1970).

11. OSHA, 29 U.S.C. $\S \S 651-78$; Federal Coal Mine Health and Safety Act of 1969, 30 U.S.C. $\$ 801$ (1970).

12. 29 U.S.C. \$ 654(a) (1970), 
workmen's compensation. The focus has changed from compensation to prevention.

\section{B. The Problem}

To implement this new policy, Congress created an elaborate apparatus and entrusted its administration to the Secretary of Labor, just as state legislatures had entrusted administration of their safety statutes to the various cominissioners of labor. The federal administrators, like those in the states, have power to investigate, cite, conciliate, assess penalties ${ }^{13}$ and ultimately to obtain court assistance in closing an offending establishment or requiring the correction of defects. ${ }^{14}$ In addition, the OSHA administrators may engage in research and developinent of safety standards, ${ }^{15}$ promulgate these standards through rules, regulations and guidelines, ${ }^{16}$ and process complaints and ensure coinpliance by imitiating their own verification systems. ${ }^{17}$ The statute does not, however, explicitly create a cause of action by the workers subject to the hazards in the workplace.

As comprehensive as this apparatus may appear, OSHA seems to be failing. ${ }^{18}$ Its problems accentuate the current skepticisin about the capacity of administrative and regulatory agencies to accomplish the missions given them by Congress. ${ }^{19}$ Evidence of past failures in many areas exists, ${ }^{20}$ and the record in the field of industrial safety is no exception. ${ }^{21}$ In addition, implementation of the new policies assuring the safety of workers may conflict with the Secretary of Labor's concern for the equilibrium between labor and management and other more general interests. ${ }^{22}$ The Secretary cannot single-mindedly dedicate

13. See OSHA $\$ \S 6,8,9,17,29$ U.S.C. $\$ \S 655,656,657,658$ (1970).

14. Id. $\S 13,29$ U.S.C. $\S 662$.

15. Id. $\$ 20,29$ U.S.C. $\$ 669$.

16. Id. $\$ 6,29$ U.S.C. $\$ 655$.

17. Id. \& 8, 29 U.S.C. $\& 657$.

18. See Page and Munsing, Occupational Health and the Federal Government: The Wages Are Still Bitter, 38 LAW \& CONTEMP. Prob. 651 (1974); Williams, OSHA under Inspection, 9 Trual 12 (July-Aug. 1973) (views of Sen. Harrison Williams, Chairman of the Senate Labor Committee, which has oversight jurisdiction); and text at notes 59-72 infra.

19. See generally, K. DAvis, DiscretionaRY JUSTICE (1969); Stewart, The Reformation of American Administrative Law, 88 HARv. L. REv. 1669 (1975).

20. For a history of administrative failnre in the field of einployment discrimination, see A. BluMrosen, Equal Employment Opportunity Through Lau, Administration, and Negotiation, in BLACK EMPLOYMENT AND THE LAW 3, 9-27 (1971) [hereinafter cited as Blumrosen]. But see Jaffe, The Illusion of the Ideal Administration, 86 HARv. L. REv. 1183 (1973).

21. J. PAGe \& M. O'BrIen, BitTer WAges 69-85 (1972) [hereinafter cited as BTTTER WAGES].

22. The potential for abuse of power in this situation was documented during the "Watergate" hearings. The Senate Select Committee on Presidential Campaign Activi- 
himself to worker safety, nor does the statute require that he adopt that posture. To the contrary, the only statutory check on his activities is couched in such a way that the worker must bear the difficult burden of proving that the Secretary acted arbitrarily in failing to seek injunctions against imminent dangers. ${ }^{23}$

One antidote to the pattern of administrative ineffectiveness emerged in the 1960's as a result of the compromise that produced Title VII of the Civil Rights Act of 1964. ${ }^{24}$ Under that statute, the individual worker retains the right to seek court enforcement of fair employment practices regardless of the action or inaction of the administrative agency. This dual remedy permits a complainant to obtain the advantages of administrative implententation of statutes plus the single-minded devotion to mdividual rights most possible in a private cause of action. In several other regulatory fields, Congress and the courts have recognized the value of allowing a private "attorney general"25 to assert social or group interests as well as individual interests when public enforcement is clearly insufficient to vindicate these interests.

This Article will consider whether a private cause of action to enjoin an occupational hazard is available to support the newly expressed policies concerning worker safety. The emphasis in OSHA on prevention iniphes that workers are no longer forced to choose between health and safety or their jobs. They are entitled to work under healthful and safe conditions. Therefore, equity jurisdiction may have

ties of 1972 uncovered a confidential memorandum from the then Assistant Secretary, U.S. Department of Labor, to the then Under Secretary, U.S. Department of Labor. In the memo, dated June 14, 1972, the Assistant Secretary outlined the activities of OSHA through the 1972 election campaign. He stated that "no highly controversial standards (i.e. cotton dust, etc.) will be proposed by OSHA or NIOSH" and that the activities of the standards advisory committees would be low-keyed. He also suggested providing the Republican National Committee and the Committee to Re-elect the President with a copy of OSHA's recruiting and hiring plans for the time during the campaign. OSHA could then consider those applicants the Committee proposed. He concluded by emphasizing the "great potential of OSHA as a sales poimt for fund raising and general support by employers" and soliciting suggestions "as to how to promote the advantages of four more years of properly managed OSHA for use in the campaign." Executive Session Hearings Before the Select Comm. on Presidential Campaign Activities of the U.S. Senate, 93d Cong., 2d Sess., Book 19, at 8801-03 (1974).

23. OSHA $\$ 13(d), 29$ U.S.C. $\$ 662$ (d) (1970). See also Hadnott v. Laird, 463 F.2d 304 (D.C. Cir. 1972).

24. 42 U.S.C. $\$ \$ 2000$ e to $2000 \mathrm{e}-17$ (1972).

25. This "private attorney general" rationale is currently emerging in the federal courts in public interest litigation as a necessary supplement to congressionally mandated administrative enforcement efforts. For a listing of statutes authorizing attorneys' fees in private actions to enforce public policies, many of which also have administrative enforcement procedures, see Alyeska Pipeline Service Co. v. Wilderness Soc., 421 U.S. 240, 260-61 n.33 (1975). See Bradley v. School Bd., 416 U.S. 696 (1974); Hall v. Cole, 412 U.S. 1 (1973); Mills v. Electric Auto Lite Co., 396 U.S. 375 (1970); Newman v. Piggie Park Enterprises, Inc., 390 U.S. 400 (1963). 
to be invoked to protect this interest in worker safety when the administrative process is inadequate to the task.

In considering this issue, the Article first examines whether OSHA contains explicit or implicit statutory language allowing a worker to inaintain an action for injunctive relief. Concluding that the Act does not provide for such relief, the Article suggests that an injunction based on the state law duty of the employer to provide a reasonably safe place to work fits comfortably within existing principles of equity. Such equitable relief is precluded by neither the existence and use of administrative remedies available under OSHA nor the existence of a collective bargaining agreement. Rather, in appropriate cases, equitable relief is available to simultaneously protect workers' rights and spur administrative action in implementing the principles of OSHA.

II

\section{Private Actions Under OSHA}

OSHA does not expressly create a private right of action for violation of either the general duty clause or the standards promulgated under the Act. To determine whether such a duty can appropriately be implied, as is frequently done in other areas of the $1 \mathrm{law}^{26}$ requires an examination of the entire statutory scheme. ${ }^{27}$ The statute vests primary responsibility for enforcement in the Secretary of Labor (the Occupational Safety and Health Administration). It creates separate administrative bodies to develop safety standards (the National Institute for Occupational Safety and Health under the Department of Health, Education, and Welfare) and to hear and decide questions of violation (the Occupational Safety and Health Review Commission). The existence of this elaborate administrative mechanism not only clearly implies that Congress did not intend to rely on the federal courts for primary enforcement of the statute, but also suggests that no private cause of action was anticipated. ${ }^{28}$

This conclusion is buttressed by the language of section 4(b)(4) of the Act: ${ }^{29}$

26. See Note, Implying Civil Remedies from Federal Regulatory Statutes, 77 HARv. L. Rev. 285 (1963); Gomez v. Florida State Employment Serv., 417 F.2d 569 (5th Cir. 1969).

27. For an extensive discussion of the problem of implication, see Martinez v. Behring's Bearings Serv., Inc., 501 F.2d 104, 105-08 (5th Cir. 1974) (dissenting opimion).

28. See Calhoon v. Harvey, 379 U.S. 134 (1964); Martinez v. Behring's Bearings Serv., Inc., 501 F.2d 104 (5th Cir. 1974).

29. OSHA \& $4($ b) (4), 29 U.S.C. \& 653(b) (4) (1970). 
Nothing in this Act shall be construed to supersede or in any manner affect any workmen's compensation law or to enlarge or diminish or affect in any other manner the common law or statutory rights, duties, or liabilities of employers and employees under any law with respect to injuries, diseases or death of employees arising out of, or in the course of, employment.

Several courts of appeal have held that this section demonstrates congressional intent not to create a new federal cause of action for violation of OSHA: ${ }^{30}$ The cases deny a federal cause of action on two grounds: (1) a presumed congressional intent based on both the extensive administrative apparatus created to enforce OSHA and on the language of section 4(b)(4); and (2) a pragmatic judgment that the administrative apparatus is sufficient to effectuate the substantive policies of OSHA. Given the heavy additional burden on the federal judiciary, which would be created by a contravening interpretation, this situation is likely to prevail. ${ }^{31}$ Nevertheless, this does not imply a limitation on state court adaptation and use of the common law in order to further the new emphasis on prevention of occupational imjuries.

\section{III}

\section{The Common LaW Duty: The Emergence of the RIGHT TO WORK UNDER SAFE CONDITIONS}

In processing thousands of tort cases from the middle of the 19th century through the first decades of this century, the common law courts shaped the negligence action of worker against employer for industrial injuries. The employer's duty was to take reasonable care ${ }^{32}$

30. Byrd v. Fieldcrest Mills, Inc., 496 F.2d 1323 (4th Cir. 1974); Russell v. Bartley, 494 F.2d 334 (6th Cir. 1974); Skidmore v. Travelers Ins. Co., 356 F. Supp. 670 (E.D. La. 1973), affd per curiam, 483 F.2d 67 (5th Cir. 1973). In addition, see Jeter v. St. Regis Paper Co., 2 OSHC 1591, 1594 (5th Cir. 1973): "The provisions for enforcement of OSHA and the Regulations promulgated thereunder are sufficiently comprehensive to make such a private right of action unnecessary to effectuate the congressional policy underlying the substantive provisions of the statute."

31. The commentators divide. Compare Miller, The Occupational Safety and Health Act of 1970 and the Law of Torts, 38 LAw \& CONTEMP. PROB. 613, 628-29 (1974), with Comment, Federal Common Law Remedies under the Occupational Safety and Health Act of 1970, 47 WASH. L. REv. 629 (1972). Contrast the express creation of a federal cause of action for damages and injunctive relief under the Consumer Products Safety Act, 15 U.S.C. $\$ \$ 2072-73$ (1972).

32. See Prosser, supra note $5, \S 80$, at 527-28. Citations to cases from four representative jurisdictions have been selected to illustrate some of the points made in the text. Alabama: Hardy v. Dothan, 234 Ala. 664, 176 So. 449 (1937); Gentry v. Swann Chem. Co., 234 Ala. 313, 174 So. 530 (1937); Robinson Minina Co. v. Swiney, 206 Ala. 617, 91 So. 476 (1921); California: Hallower v, Henley, 6 Cal. 209 (1856); Hall v. Burton, 201 Cal. App. 2d 72, 19 Cal. Rptr. 797 (1st Dist. 1962); Watts v. Murphy, 9 Cal. App. 564, 99 P. 1104 (3d Dist. 1908); Illinois: Swiecz v. Illimois Steel Co., 231 IIl. 456, 83 N.E. 168 (1907); Scott v. McMenamin, 51 Ill. App. 121 (1893); Linquist 
to provide both a safe place to work ${ }^{33}$ and safe equipment, ${ }^{34}$ to instruct where necessary, to warn of dangers not likely to be observed by the worker, ${ }^{35}$ and to provide reasonably safe fellow workers ${ }^{36}$ in sufficient numbers. ${ }^{37}$ Custom was evidence of reasonableness, which meant that

v. Hodges, 152 III. App. 491 (1910), aff'd, 248 IIl. 491, 94 N.E. 94 (1911); New Jersey: MacDonald v. Standard Oil Co., 69 N.J.L. 445, 55 A. 289 (Err. \& App. 1903).

33. Alabama: Forman v. Dorsey Trailers, Inc., 256 Ala. 253, 54 So. $2 \mathrm{~d} 499$ (1951); Hardy v. Dothan, 234 Ala. 664, 176 So. 449 (1937); Gentry v. Swann Chem. Co., 234 Ala. 313, 174 So. 530 (1937); Langhorne v. Simington, 188 Ala. 337, 66 So. 33 (1914); California: Brown v. Sharp-Hauser Contracting Co., 159 Cal. 89, 112 P. 874 (1910); Thompson v. California Constr. Co., $148 \mathrm{Cal}$. 35, 82 P. 367 (1905); Pre v. Standard Portland Cement Co., 9 Cal. App. 596, 100 P. 122 (3d Dist. 1908); Hersperger v. Pacific Lumber Co., 4 Cal. App. 460, 88 P. 587 (3d Dist. 1906); Illinois: Mueller v. Elm Park Hotel Co., 398 Ill. 60, 75 N.E.2d 314 (1947); Deerimg Harvester Co. v. Barzak, 227 Ill. 71, 81 N.E. 1 (1907); Ill. Steel Co. v. Schymanowski, 162 Ill. 447, 44 N.E. 876 (1896); Miller v. Russell, 302 Ill. App. 165, 23 N.E.2d 775 (1939); New Jersey: Clayton v. Ainsworth, 122 N.J.L. 160, 4 A.2d 274 (Err. \& App. 1939); Davis v. New Jersey Zinc Co., 116 N.J.L. 103, 182 A. 850 (Err. \& App. 1936); MacDonald v. Standard Oil Co., 69 N.J.L. 445, 55 A. 289 (Err. \& App. 1903); Estell v. Board of Education, 26 N.J. Super. 9, 97 A.2d 1 (App. Div. 1953); Cichocki v. Geig Co., 14 N.I. Misc. 232, 183 A. 463 (Hudson County Cir. Ct. 1936); Meany v. Standard Oil Co., 55 A. 653 (Sup. Ct. 1903).

34. Alabama: Robinson Mining Co. v. Swiney, 206 Ala. 617, 91 So. 476 (1921); California: Brymer v. Southern Pac. Co., 90 Cal. 496, 27 P. 371 (1891); Hall v. Burton, 201 Cal. App. 2d 72, 19 Cal. Rptr. 797 (1st Dist. 1962); Elder v. Rose, 63 Cal. App. 545, 219 P. 74 (3d Dist. 1923); Illinois: Pfeifer v. Eastern Metal Works, 258 Ill. 427, 101 N.E. 548 (1913); Consolidated Coal Co. v. Haenni, 146 Ill. 614, 35 N.E. 162 (1893); Sprickerhoff v. Baltimore \& O.R.R., 323 Ill. App. 340, 55 N.E.2d 532 (1944); New Jersey: Clayton v. Ainsworth, 122 N.J.I. 160, 4 A.2d 274 (Err. \& App. 1939); MacDonald v. Standard Oil Co., 69 N.J.L. 445, 447, 55 A. 289, 290 (1903).

35. Alabama: Hardy v. Dothan, 234 Ala. 664, 176 So. 449 (1937); Reed v. Rideout's Ambulance, Inc., 212 Ala. 428, 102 So. 906 (1925); Robinson Mining Co. v. Swiney, 206 Ala. 617, 91 So. 476 (1921); Citizen's Light Heat \& Power Co. v. Lee, 182 Ala. 561, 62 So. 199 (1913); Woodward Iron Co. v. Lewis, 171 Ala. 233, 54 So. 566 (1911); California: Baez v. Southern Pacific Co., 210 Cal. App. 2d 714, 26 Cal. Rptr. 899 (3d Dist. 1962); Brown v. Stanford Univ., 41 Cal. App. 100, 182 P. 316 (3d Dist. 1919); Illinois: Collins v. Kurth, 322 Ill. 250, 153 N.E. 355 (1926); Consolidated Coal Co. v. Haenni, 146 IIl. 615, 35 N.E. 162 (1893); Fitzpatrick v. Illinois Cent. R.R., 154 III. App. 623 (1910); Chicago R.I. \& P. Ry. v. Daugaard, 118 IIl. App. 67 (1905); New Jersey: Ludwig v. Kirby, 13 N.J. Super. 116, 80 A.2d 239 (App. Div. 1951) (master must instruct minors how to avoid hazards of the business); Tulpom v. Cantor, 87 N.J.L. 213, 93 A. 573 (Err. \& App. 1915); Ramsey v. Raritan Copper Works, 78 N.J.L. 474, 74 A. 437 (Err. \& App. 1909).

36. Alabama: Langhorne v. Simington, 188 Ala. 337, 66 So. 85 (1914); SlossSheffield Steel \& Iron Co. v. Smith, 166 Ala. 437, 52 So. 38 (1910); California: Matthews v. Bull, 116 Cal. 316, 47 P. 773 (1897); Gier v. Los Angeles Consol. Elec. Ry., 188 Cal. 129, 41 P. 22 (1895); Illinois: R.R. Supply Co. v. Klofski, 138 Ill. App. 468, aff'd, 235 Ill. 146, 85 N.E. 274 (1908); Burnett v. Caho, 7 Ill. App. 3d 266, 285 N.E.2d 619 (1972); New Jersey: MacDonald v. Standard Oil Co., 69 N.J.L. 445, 55 A. 289 (1903); Butler v. Eberstadt, 113 N.J.L. 569, 175 A. 159 (Err. \& App. 1934) (master is liable to a worker in a third-party action when he has been negligent in selecting the worker at fault, or in retaining him after notice of his imcompetency); McAndrews v. Burns, 39 N.J.L. 117 (Err. \& App. 1876).

37. Alabama: Seymour v. Holman, 229 Ala. 634, 158 So. 525 (1934); Alabama 
the safety practices generally used in the industry were deemed appropriate. But the courts did not abdicate to industry the entire task of fashioning safety standards. ${ }^{38}$ The courts recognized that "[e]ven an entire industry, by adopting such careless methods to save time, effort or money, cannot be permitted to set its own uncontrolled standard."3o Therefore, they were willing to establish standards of conduct "where common knowledge and ordimary judgment will recogmize unreasonable danger." ${ }^{40}$

Employer neghigence under these common law rules was often offset and hability denied, however, by the defenses of contributory neghigence, assumption of risk, and fellow servant. ${ }^{41}$ The nature of the first two of these defenses deserves examination, in light of the new OSHA emphasis on the prevention of imjuries.

\section{A. Contributory Negligence and Assumption of Risk}

Inadvertence to risks that should have been known, or continued activity in the face of known danger, were the hallmarks of these defenses. ${ }^{42}$ Hence, the more glaring the employer's failure to provide safe conditions, the less likely it was that the worker could recover. At most, the common law provided an incentive to the employer to warn of the danger, even though it was likely that youthful enthusiasm or fimancial imperatives would keep the worker on the job anyway. If the peril materialized after the requisite warning had been given, the burden of injury would be on the worker.

Great Southern R.R. v. Vail, 142 Ala. 134, 38 So. 124 (1904); California: see, e.g., The Pioneer, 78 F. 600 (N.D. Cal. 1897); Illinois: Supple v. Agnew, 191 Ill. 439, 61 N.E. 392 (1901); Swift \& Co. v. Rutkowski, 182 Ill. 18, 54 N.E. 1038 (1899).

38. Alabama: Caldwell-Watson Foundry \& Machine Co. v. Watson, 183 Ala. 326, 62 So. 859 (1913) (evidence other prudent men use machine is pertinent but not conclusive); Prattville Cotton Mills Co. v. McKinney, 178 Ala. 554, 59 So. 498 (1912); Davis v. Kornman, 141 Ala. 479, 37 So. 789 (1904); California: Pauly v. King, 44 Cal. 2d 649, 284 P.2d 487 (1955); Diamond v. Grow, 243 Cal. App. 2d 396, 52 Cal. Rptr. 265 (5th Dist. 1966); see also Alber v. Owens, 66 Cal. 2d 790, 427 P.2d 781, 59 Cal. Rptr. 117 (1967); Illinois: Kay v. Ludwick, 87 Ill. App. 2d 114, 230 N.E.2d 494 (1967); Sorenson v. Illinois Cent. R.R., 155 Ill. App. 606 (1910); New Jersey: Rukowski v. Raybestos-Manhattan, Inc., 5 N.J. Super. 203, 68 A.2d 641 (App. Div. 1949); Tompkins v. Marine Engine \& Machine Co., 70 N.J.L. 330, 58 A. 393 (Err. \& App. 1904).

39. Prosser, supra note 5 , \& 33, at 167.

40. Id., at 138. Alabama: see cases cited in note 38 supra; California: Mehollin v. Ysuchiyama, 11 Cal. 2d 53, 77 P.2d 855 (1938); Anstead v. Pacific Gas \& Electric Co., 203 Cal. 634, 265 P. 487 (1928); Illinois: Kay v. Ludwick, 87 Ill. App. 2d 114, 230 N.E.2d 494 (1967); Hopwood v. Thomas Horst Co., 71 I11. App. 2d 434, 219 N.E.2d 76 (1966); Kylander v. Chicago Short Line Ry., 19 Ill. App. 2d 29, 153 N.E.2d 812 (1958); Chicago, R.I. \& P. Ry. v. Daugaard, 118 Ill. App. 67 (1905); New Jersey: Wellenheider v. Rader, 49 N.J. 1, 227 A.2d 329 (1967).

41. See cases cited in note 40 supra.

42. HARPER \& JAMES, supra note $8, \S 21.4$, at $1176-77, \S 22.6$, at 1214. 
It was assumed that the worker should protect himself against such risks. But workers could not compel the employer to provide safe conditions. Thus, the only course open to the worker was to refuse to work under hazardous conditions and risk discharge. Since most employment contracts were at will, the worker could leave without risk of hability in contract; and if the employer sued for breach, the failure to provide safe conditions might have provided a defense. The common law left the worker free to resign, but unable to remain at work and insist on safe conditions. ${ }^{43}$ This failure of the common law to sufficiently protect workers against unsafe conditions was noted by at least one court: "Common experience everywhere registered in tables of gruesome statistics, affords fresh demonstration every day of the madequacy of the common-law doctrine of reasonable care to provide places and instrumentalities reasonably safe against foreseeable occurrences. .944

In the 20th century, the common law rules were supplemented by safety standards that were either written into legislation or promulgated by administrators. ${ }^{45}$ The courts held violation of these standards to be evidence (or, at times, even actual proof) of the breach of the employer's duty. ${ }^{46}$ Many courts concluded that the defenses of contributory negligence or assumption of risk were not available in actions based on these safety standards. One decision refused to allow the defense of contributory negligence:

Workmen ... are scarcely in a position to protect themselves from accident. They usually have no choice but to work with the equip-

43. The argument that the "economic compulsion" to work rendered the choice unfree was rarely accepted in America. Id. $\$ 21.4$, at 1176; Prosser, supra note 5, $\S$ 80 , at 527-28.

44. Casper v. Lewin, 82 Kan. 604, 624, 109 P. 657, 664 (1910), appeal dismissed, 223 U.S. 736 (1911).

45. BITTER WAGES, supra note 21 , at 69-85.

46. HARPRR \& JAMES, supra note $8, \S 17.5, \S 17.6$ at 987-1014; Prosser, supra note $5, \S 35$, at 200-03, and $\S 68$, at 453. See Alabama: Smith v. Wolf, 160 Ala. 644, 49 So. 395 (1909) (failure to keep stretcher, blankets, bandages, etc. as required by statute, CODE OF ALA., tit. 26, $\$ 145$ (1958), is proof of negligence of the employer); California: Alber v. Owens, 66 Cal. 2d 790, 794-95, 427 P.2d 781, 784, 59 Cal. Rptr. 117, 120 (1967) (violation of employer's statutory duty is neghigence per se and may be negligence as well); Illinois: U.S. Brewing Co. v. Stoltenberg, 211 IIl. 531, 71 N.E. 1081 (1904) (failure to perform statutory duty is prima facie evidence of negligence); True and True Co. v. Woda, 201 Ill. 315, 66. N.E. 369 (1903) (same); Stivers v. Black \& Co., 315 III. App. 38, 42 N.E.2d 349 (1942) (same); Dini v. Naiditch, 20 Ill. 2d 406, 170 N.E.2d 881 (1960) (violation of statutory duties are prima facie evidence of negligence only when the legislation involved is a public safety ineasure designed for the protection of human life or property); Gillette v. Anderson, 4 Ill. App. 3d 838, 282 N.E.2d 149 (1972) (same); New Jersey: Gibilterra v. Rosemawr Homes, Inc., 19 N.J. 166, 115 A.2d 553 (1955) (safety code could not be basis of liability of a property owner for injuries to an employee of a contractor); Evers v. Davis, 86 N.J.L. 196, 90 A. 677 (Err. \& App. 1914). 
ment at hand though danger looms large. The legislature recognized this and to guard against the known hazards of the occupation required the employer to safeguard the workers from injury. . . . If the employer could avoid this duty by pointing to the concurrent negligence of the injured worker in using the equipment, the beneficial purpose of the statute might well be frustrated and nullified. ${ }^{47}$

Still another court rejected the defense of assumption of risk in a case involving violations of safety statutes.

To hold that he did assume the risk would be equivalent to a repeal of the statute, since it would be a continuing invitation to the company to forbear compliance with its provisions. The statute was passed under the police power of the state for the purpose of protecting those who are unable to protect themselves, occupying as they necessarily do a position much inferior in financial security to that of their employers; the physical necessity of themselves and their families making it essential that they should lave work in order to secure the means of sustenance. It would defeat this beneficent purpose if it should be admitted as a sound principle that a failure of the employer to obey the statute could be condoned by the employe[e]. Such a conclusion would place the employer in the position of power which only the Legislature should occupy, since it would enable him to either destroy or maintain the policies of the state according to his own will and purpose. 48

These decisions, arrived at without specific statutory authority, maintained that a worker should not have to choose between working under dangerous conditions or quitting. They constitute early judicial recognition of the right to work under safe conditions.

\section{B. The Injunction}

Employer liability acts and workınen's compensation laws ${ }^{40}$ modi-

47. Koenig v. Patrick Constr. Corp., 298 N.Y. 313, 318-19, 63 N.E.2d 133, 135 (1948). See, e.g., Alabama: Foley v. Pioneer Mining \& Mfg. Co., 144 Ala. 178, 40 So. 273 (1906); Illinois: Thomas v. Chicago Embossing Co., 307 Ill. 134, 136 N.E. 285 (1923); Brunnworth v. Kerens-Donnewald Coal Co., 260 Ill. 202, 103 N.E. 178 (1913); New Jersey: Volpe v. Hammersley Mfg. Co., 96 N.J.L. 489, 115 A. 665 (Err. \& App. 1921).

48. American Zinc Co. v. Graham, 132 Tenn. 586, 589, 179 S.W. 138, 139-40 (1915). See, e.g., Alabama: Citizens' Light, Heat \& Power Co. v. Lee, 182 Ala. 561, 62 So. 199 (1913); Pratt Consol. Coal Co. v. Davidson, 173 Ala. 667, 55 So. 886 (1911); California: Finnegan v. Royal Realty Co., 35 Cal. 2d 409, 430, 218 P.2d 17, 30-31 (1950); Widman v. Rossmoor Sanitation, Inc., 19 Cal. App. 3d 734, 749, 97 Cal. Rptr. 52, 60-61 (4th Dist. 1971); Eberhard v. Bruhn, 13 Cal. App. 3d 836, 91 Cal. Rptr. 915 (2d Dist. 1970); New Jersey: Volpe v. Hammersley Mfg. Co., 96 N.J.L. 489, 115 A. 665 (Err. \& App. 1921); Lesko v. Liondale Bleach Dye \& Print Works, 93 N.J.L. 4, 107 A. 275 (1919); Illinois: Waschow v. Kelly Coal Co., 245 Ill. 516, 92 N.E. 303 (1910); Landgraf v. Kuh, 188 III. 484, 59 N.E. 501 (1900).

49. Alabama: CoDE of ALA., tit. 26, \$253 (Supp. 1969); see Alabama By-Prod- 
fied the common law only with respect to damages. The negligence complex remains the appropriate body of law if a worker seeks an injunction against continuing occupational hazards. The action to enjoin occupational hazards is based on the state law duty of reasonable care. The defenses of assumption of risk and contributory negligence, abolished by workmen's coinpensation laws, relate only to damage liability and are therefore inappropriate to an injuctive proceeding. ${ }^{50}$

Injunctive relief will spur the agencies to effective aotion and strengthen the right to work under safe conditions. Since injunctive rehef will be available only where administrative efforts have been inadequate, each injunction will provide record evidence of administrative failure. Without this remedy, the right to work under safe conditions will not be fully vindicated where the administrative apparatus fails. The ability to quit a job where safe conditions are not maintained does not vindicate the right, for the right is to remain at work under safe conditions. It is unlikely that a refusal to work by a few workers will improve occupational conditions. It is even nore unrealistic to assume that many empolyees will quit en masse or strike over health and safety issues. Nor should the workers' right to strike over safety conditions be seen as their only renedy. ${ }^{51}$ Actions to enjoin occupational hazards may be brought by anyone threatened by the unsafe conditions. They may be brought by individual employees, local labor organizations, ${ }^{52}$

ucts Co. v. Landgraff, 32 Ala. App. 343, 27 So. 2d 209 (1946), aff'd, 248 Ala. 253, 27 So. 2d 215 (1946); California: CaL. LABoR Code $\$ 3201$ (West 1971); see Carrigan v. California State Legislature, 263 F.2d 560 (9th Cir. 1959), cert. denied, 359 U.S. 980 (1959); Illinois: S.H.A. ch. 48, $\$ 138.11$ (1966) (relief exclusively damages); S.H.A. ch. 48, § 172.40 (1966) (same); New Jersey: N.J.S.A. 34: 15-8 (Supp. 1975).

50. The argument may be made that OSHA § 5(b), 29 U.S.C. $\$ 654$ (b) (1970), which provides, "Each employee shall comply with occupational safety and health standards and all rules, regulations and orders issued pursuant to this Act which are applicable to his own actions and conduct," incorporates notions of employee responsibility, and lence of the possibility of contributory negligence, into the statute. The matter is accurately discussed and resolved in Miller, The Occupational Safety and Health Act of 1970 and the Law of Torts, 38 LAW \& ConTEMP. Prob. 612, 633-35 (1975). See generally National Realty \& Constr. Co. v. Occupational Safety and Health Review Comm'n, 489 F.2d 1257 n.39 (D.C. Cir. 1973). Since the action for an injunction will have been commenced before the hazard ripened into harm, the doctrines of contributory negligence and assumption of risk, which are oriented to "after the fact" damage actions are not applicable. The concepts underlying these doctrines, lowever, may be raised defensively by an employer, in equity, who might argue that the failure of the plaintiff or the union if one exists to raise these matters at the earliest point in time constituted latches. The thrust of the Act itself toward prevention of injuries, however, requires rejection of this argument.

51. See generally Atleson, Threats to Health and Safety: Employee Self-Help Under the NLRA, 59 MinN. L. REv. 647 (1975) [hereinafter cited as Atleson].

52. In reality, the vulnerability of the employee to retaliation by the employer may deter many individual actions. It is more likely that a union would provide the vehicle for bringing such injunctive actions. In deciding whether to bring such an action, how- 
and may even be brought as class actions. ${ }^{53}$

IV

\section{Equitable Protection for thlz INTERest IN Physical SAFETy}

\section{A. General Considerations}

The protection of workers from recurrent risks of injury fits well within the traditional concepts of equity. The harm is clearly irreparable in that bodily imjury can never be fully compensated by any scheme of monetary damages.

Equity has often been invoked to protect physical safety in nuisance cases involving adjoining landowners. ${ }^{5 / 4}$ The courts have not required landowners to choose between tolerating unsafe conditions or moving. Once it is recognized that the worker has a right to remain at work under safe conditions, these landowner-nuisance cases become appropriate analogies.

ever, a union must consider more than the interests of those threatened by the hazard. Consideration of the interests of the union mentbership as a whole, as well as its possible obligations under a current collective bargaining agreentent (possibly containing a grievance procedure covering working conditions), would influence this decision. Thus, the availability of a union cause of action may not fully vindicate the policy of occupational safety.

53. Alabama: Code of ALA., tit. 7, $\$ 128$ (Supp. 1973); California: CaL. CODE Crv. Pro. $\$ 378$ (West 1971); Illinois: Although there are no state statutes in Illinois that authorize and define class action suits, such suits are recognized by case law. E.g., Newberry Library v. Board of Educ., 387 Ill. 85, 90, 55 N.E.2d 147, 151 (1944); New Jersey: N.J. CT. R. 4:32 (1972).

54. Alabama: Colenian v. Estes, 281 Ala. 234, 201 So. 2d 391 (1967); Nevin v. McGavock, 214 Ala. 93, 106 So. 597 (1925); Nixon v. Boling, 145 Ala. 277, 40 So. 210 (1906) (the jurisdiction of a court of equity to enjoin a continuing nuisance and conpelling its abatement is too well settled to admit of cuestion); California: Dauberman v. Grant, 198 Cal. 586, 246 P. 319 (1926) (smoke and soot); People v. Selby Snelting \& Lead Co., 123 Cal. 84, 124 P. 692 (1912) (smelting plant fumes); Wado v. Campbell, 200 Cal. App. 2d 54, 19 Cal. Rptr. 173 (5th Dist. 1962) (dairy operation); San Diego County v. Carlstrom, 196 Cal. App. 2d 485, 16 Cal. Rptr. 667 (4th Dist. 1961) (extrenie fire hazard near residential area); Alonso v. Hills, 95 Cal. App. 2d 778, 214 P.2d 50 (1st Dist. 1950) (blasting); Centoni v. Ingalls, 113 Cal. App. 192, 298 P. 47 (4th Dist. 1931) (dust pollution); Donahue v. Stockton Gas \& Elec. Co., 6 Cal. App. 276, 92 P. 196 (3d Dist. 1907) (air pollution by a factory); Illinois: People v. Anderson, 355 IIl. 289,189 N.E. 338 (1934); Oehler v. Levy, 234 Ill. 595, 85 N.E. 271 (1908); Wahle v. Reinach, 76 Ill. 322 (1875); Rand v. Wilber, 19 Ill. App. 395 (1885); New Jersey: Benton v. Kernan, 127 N.J. Eq. 434, 13 A.2d 825 (1940); Hennessey v. Carmony, 50 N.J. Eq. 616, 620, 25 A. 374, 378 (1392) (where, in granting an injunction in response to a charge that vibrations from defendants' machines disturbed plaintiff's property, the court stated: "[T]t is inequitable and unjust that the injured party should be compelled to resort to repeated actions at law to recover damages . . . which $\ldots$ in this class of cases are incapable of measurement . . . . This ground of equitable action is of itself sufficient in those cases where the injury ... promises to be repeated for an indefinite period...."). 
Equity will not act on speculative causes and, therefore, the risk of injury inust be establislied with clarity. This can often be done. Government-coinpiled statistics document the precise incidence of injuries from occupational hazards within each industry. ${ }^{55}$ Furthermore, the presence of occupational hazards can be objectively demonstrated. In an action to enjom a hazard there may have been injuries that were redressed by workmen's compensation. The danger may have been regulated by a safety standard or the subject of a published study. Moreover, if the risk is apparent to the "ordinary person," equity can enable a court to act without the panoply of reports or studies so characteristic of modern regulation.

\section{B. The Inadequacy of the Remedy at Law}

Injunctions are normally issued to protect against continuing hazards and recurrent risks. ${ }^{56}$ The rationale for such restraints- that the remedy at law is madequate because the controversy involves a multiplicity of suits concerning the same circumstances-is singularly appropriate in the case of an industrial hazard. Moreover, recurrent workmen's compensation claims reflect the constant exposure of workers to occupational hazards.

The existence of federal and state procedures to enforce the riglt to work under safe conditions suggests the need to exhaust the administrative remedies before recourse to the courts. A showing that the administrative remedy is not likely to be effective, however, will invoke the futility exception to the exhaustion doctrine, ${ }^{57}$ establish the inadequacy of the legal remedy and thus justify equitable relief.

\section{The Initial Failures of $O S H A$}

A review of the initial phases of OSHA's implementation indicates that effective, prompt law enforcement has not occurred. ${ }^{58}$ The OSH

55. As reported by Stellman and Daum, figures show that over 14,000 workers are killed each year and over 2.2 million more are permanently or temporarily disabled. The authors point out that these numbers do not include the nearly half million workers suffering from occupational diseases. An 8-10 percent under-reporting rate must be kept in mind when studying this figure. J. STELLMan AND S. DaUM, M.D., Work IS DaNGerOUS TO YOUR HEALTH 3, 4 (1973).

56. The Supreme Court has long recognized that injunctive rehef is appropriate when the injury or risk is a recurring one: "A suit at law could only have determmed the particular wrong occurring on a particular occasion, and would not reach other wrongs of like character that would occur almost every hour of each day .... Only a court of equity was competent to ... . determine finally and once for all [sic] the entire controversy between the parties-thus avoiding a multiplicity of suits and conserving the public interests." Dounovan v. Pennsylvania Co., 199 U.S. 279, 305 (1905).

57. K. Davis, Administrative LaW Text 391-92 (3d ed. 1972).

58. See materials cited at note 18 supra. 
Administration is severely understaffed ${ }^{58}$ and underfunded. ${ }^{80}$ It is estimated that 95 percent of the working places covered by the Act have yet to be inspected. ${ }^{81}$ At the present rate, it will take up to 12 years for inspectors to visit each site. ${ }^{62}$ Current enforcement efforts are simply not sufficient to effectuate the statute's broad nandate for safe working conditions. A high percentage of cited violations are categorized as nonserious; ;3 and, as one report indicates, even when fatal or catastrophic accidents occur, citations for serious violations rarely issue. ${ }^{64}$ State plans need not require enforcement action (i.e., abatement periods) following OSHA findings of serious violations as long as the plans include consultation services to industry. Nor must states schedule follow-up visits after the consultations occur. ${ }^{85}$

In addition, penalties for violations are low. ${ }^{6 B}$ The OSH Administration will now approve state plans that include either no penalties or penalties that are less severe than the sanctions required by comparable federal standards, if it is satisfied that the state's imspections will be more effective than federal inspections will be. ${ }^{67}$ Furthermore, it is not difficult for industry to obtain modifications of hazard abatements that have been ordered by the Administration. ${ }^{88}$ The overwhelming number of modifications granted by OSHA undercut its potential power to alleviate occupational hazards. Nor has the plan to attack the worst occupational conditions first been effectively implemented. No violations were cited in almost half of the initial inspections of target industries. ${ }^{60}$

The OSH Administration is not the only source of administrative

59. As of Sept. 1974 there were 754 federal safety and health inspectors to cover 4.1 million working places. 4 BNA Occ. SAFETY AND HeALTH REP. 383 (Sept. 5, 1974).

60. Id. at 251 (Aug. 8, 1974).

61. Estimated by Senate Committee on Labor and Public Welfare Subcommittee on Labor in an OSHA-related issue paper. Id. at 395 (Sept. 12, 1974).

62. Projected by Deputy Assistant Secretary of Labor, Howard T. Schulte. Id. at 36 (May 1, 1974).

63. Information sent by Senator Harrison Williams, Chairman of the Senate Committee on Labor and Public Welfare Subcommittee on Labor, to Secretary of Labor Brennan on Sept. 5, 1974 stated that 98.7 percent of violations cited by OSHA were classified as non-serious. Id. at 395 (Sept. 12, 1974).

64. Only 17 percent of violations fonnd during investigations of fatal or catastrophic accidents were rated serious. Id. at 395 (Sept. 12, 1974).

65. OSHA Program Directive 74-13, full text published in 4 BNA Occ. Safety AND HEALTH REP. 493 (Nov. 3, 1974).

66. $\$ 16.00$ is the average penalty for nonserious violations, $\$ 648.00$ for serious violations, and $\$ 1,104.00$ for willful, repeated, or imminent danger violations. 4 BNA Occ. SAFETY ANI Health Rep. 395 (Sept. 12, 1974).

67. Id. at 36 (May 13, 1974).

68. The Occupational Safety and Health Review Commission calculated that 89.4 percent of petitions for modifications of abatements received from Jan. 1, 1974 to July 31, 1974 were granted. Id. at 321 (Aug. 22, 1974).

69. Id. at 395 (Sept. 12, 1974). 
inefficiency in attacking the problems that were meant to be confronted by OSHA. The National Institute of Occupational Health and Safety (NIOSH) is the agency within the Department of Health, Education and Welfare responsible for researching and setting standards for occupational hazards. Unfortunately, slowness and imefficiency characterize its operations. For example, the list of toxic substances NIOSH published months behind schedule fails to include half of the estimated 15,000 toxic substances in industrial use. ${ }^{70}$ Moreover, NIOSH is producing the documents needed to develop standards at the rate of only 14 per year ${ }^{71}$ despite the fact that $500-600$ new substances are introduced into industrial use annually. ${ }^{72}$

\section{Failure of States' Efforts to Achieve Safe Conditions}

The enforcement mechamisin of the states work no better. The New Jersey program provides a typical example of the inadequacy. ${ }^{73}$ In

70. BrTrer WAGES, supra note 20 , at 197 . Shortly after the danger of viny] chloride was recently revealed to the public, one expert noted that the danger of the substance to workers' lealth has been known to the public since 1949. He offered little hope that NIOSH could remedy the problem due to its "woefully inadequate" funding. Address by Dr. Irving Selikoff, director of the environmental sciences laboratory, Mount Sinai School of Medicine, New York, at the 27th Annual Conference on Labor, June 12-14, 1974. LAB. REL. YeAR BooK 145 (1974).

71. Stateinent of Dr. Charles C. Edwards, Assistant Secretary for Health, Department of Health, Education and Welfare, 4 BNA OCC. SAFETY AND Health REP. 251 (Aug. 8, 1974).

72. Testimony on the implementation of OSHA by Pat Greathouse, Vice-President, International Union UAW, accompanied by George W. Strugs Jr., Occupational Safety and Health Consultant, Social Security Department UAW, before U.S. Senate Sub-Committee on Labor. Hearings on S.586 Before the Subcomm. on Labor of the Comm. on Labor and Public Welfare, 93d Cong., 2d Sess. 314 (1974).

73. Although not all of the failures of the New Jersey program are present in other state enforcement nechanisins, none appear adequate to vindicate the policy of accident prevention. The statutory patterns in California and Illinois are as follows:

California: The Division of Industrial Safety of the Department of Industrial Relations administers the California Occupational Safety and Health Act of 1973. CaL. LABOR CODE $\$ \S 6300-6708$ (West Supp. 1975). The Division can act in response to complaints as well as on its own initiative. The Act requires that notices inforning employees of their rights under the Act and of the location of the nearest office of the Division be posted at all workplaces. Any failure of the Division to respond to complaints must be explained in a written statement, and complaints are renewable. Failure to respond is justifiable if the Division considers that the coinplaints are an effort to harass the employer. Althougl the Division has broad discretion in selecting its investigations, it is required to investigate the cause of fatal accidents or accidents resulting in serious injury to five or more employees.

The power of the Division to enforce standards includes the authority to issue citations fixing abatement periods during which time hazards must be corrected. Abatement periods can be nodified if the employer evidences good faith efforts to comply. Violations uncovered during consultative visits made by the Division to worksites cannot be penalized. If occupational conditions constitute a serious menace to the lives and safety of einployees, the Division can seek an injunction to restrain the work's operations imtil 
New Jersey, a highly industrialized state, the division responsible for administering state safety laws employed 45 inspectors to check 28,000 industrial workplaces. ${ }^{74}$ Consequently, most workplaces were inspected only once every 2 years. Furthernnore, the average fine for violations was only a fraction of the allowable penalties. Thus, although the New Jersey inspectors had the power to close any plant, the operations of which threatened imminent hazards, the state agency adopted a narrow definition of "imminent hazards" and required evidence that death would immediately result before shutting down facilities. No closing was ever ordered due to threats to occupational health alone.

The most serious defect in the New Jersey program was the failure of the enforcement division to publicize ways by which workers could complain about occupational conditions. The employer was not required to post inforination about the state agency or about worker safety and health. There seems to have been no effective commumication between the workers and the agency established to protect them. In addition, until 1972 the division depended on voluntary reporting of injuries by business and industry. ${ }^{75}$ One study suggests that occupational injury rates were unaffected by the existence and enforcement of state safety legislation. ${ }^{78}$

\section{Failure of Workmen's Compensation}

Workmen's Compensation programs are designed to pay only onehalf to two-thirds of the loss suffered by injured workers. More impor-

conditions have improved. Only if the Division's action or inaction was without or in excess of its powers, was procured by fraud, was unreasonable, or was not supported by substantial evidence can parties succeed in getting judicial relief.

Illinois: SMTtH-HURD ANn. Ir工. STAT. ch. 48, § 137.1-137.21 (Smith-Hurd Supp. 1975) (the Health and Safety Act) is administered by the Industrial Commission of the Department of Labor. The Commission enforces safety standards promulgated by the federal OSH administration and proscribes rules relating to reports of work-related illnesses filed by employers. Employees may complain to the Department about violations of safety and health standards and if no action is taken they may request a hearing before the Industrial Commission. Employers can obtain temporary variances of the standards by showing that they are unable to comply with the standard by its effective date, that they are taking all available steps to safeguard employees against hazards, and that they have effective programs for compliance. Temporary and permanent variances are granted only after notice to employees and hearings which imclude employees' participation.

74. Most activities concerning occupational health and safety administered by the Division of Engineering ard Safety were terminated in January, 1975, when the New Jersey legislature refused to adopt a state plan approved by OSHA. Currently, the occupational health and safety investigatory and enforcement activities in New Jersey are performed by personnel from the federal OSH administration.

75. Information about New Jersey's occupational health and safety activities gathered in interview with Mr. Seymour Rubinstein, then Assistant Chief of Bureau of Engineering and Safety, N.J. Department of Labor, in Trenton, March 1974.

76. Sands, How Effective is Safety Legislation?, 11 J. LAw \& Econ. 165 (1968). 
tant, the compensation process has not promoted accident prevention. One study, which examined the relation between workmen's compensation benefits and conditions as reflected in imjury rates, found no clear decline in the number of work-related injuries after the legislation was first enacted. ${ }^{77}$ Despite the recent increases in benefits, there is no evidence that higher insurance premiums have motivated employers to improve hazardous conditions. ${ }^{78}$ It has been observed that:

Originally the motive which impelled employers and insurers to establish safety programs was to reduce the amounts which would be paid injured employees. . . Today that motive has lost nuch of its force with employers. ... Neither experience ratings nor retrospective ratings, each designed to reward employers with low injury rates by lower premiums, is in itself a sufficient inducement to the adoption and enforcement of sound industrial safety programs by employers. ${ }^{70}$

In fact, both the rate of injuries and the percentage of disabling injuries have increased simce 1961, and they were higher in 1970 than they had been since $1951 .^{80}$

Another problem with workmen's compensation is its failure to coordimate efforts to achieve occupational safety and health. ${ }^{81}$ The New Jersey Workmen's Compensation Study Commission reports that the state's Division of Compensation neither provides accident prevention services nor has any commumications with the state office that does. ${ }^{82}$

Given these limitations in the available programs it is extremely likely that the federal or state agencies will fail to promote occupational safety in any particular circumstance. In invoking the jurisdiction of the court, a complaming worker may not be able to rely on this general probability of failure. He may be required instead to invoke administrative remedies in advance of or concurrently with application for a temporary restraining order or preliminary injunction. Plaintiff worker's counsel may anticipate this problem by notifying the appropriate

77. Berkowitz, Aspects of the Economics of Workmen's Compensation, in NAtional Institutes on RehabILITATION aNd Health Services, RePort of the National WORKSHOP ON REHABIITATION AND WORKMEN'S COMPENSATION 13, 24 (1971).

78. The Report of the National Commission on State Workmen's ComPENSATION LAWs 96-98 (1972). See note 6 supra.

79. St. Clair, Occupational Disability-Privately Insured, in Occupatronal Disability and Public Policy 101 (B. Cheit \& M. Gordon eds. 1963).

80. The Report of the National Commission on State Workmen's ComPENSATION LAWS 89 (1972).

81. Larson, Compensation Reform in the United States, in Occupatronal Disability and Public Policy 11, 24 (B. Cheit \& M. Gordon eds. 1963).

82. The Need for Safety Services, Report of New JERSEY WORKMEN's COMPENSATION STUDY COMMISSION 5 (1973). 
agency of both the hazard and his intention to litigate shortly before filing suit.

\section{$\mathrm{V}$}

\section{State Court Actions Are Not Restricted by OSHA}

Whatever remedies can be provided by the existing state and federal agencies, their very limitations suggest that state equitable proceedings have been neither foreclosed nor preempted by congressional adoption of OSHA. OSHA and its legislative history are completely silent on the issue of state injunctions. And although questions of preemption involve many practical and theoretical matters-imcluding consideration of the congressional attitude toward retention of state power, the potential for conflict among the regulators and the practical ability to delineate in advance appropriate areas of state jurisdiction ${ }^{88}$ there is no general presumption in favor of exclusive federal subject matter jurisdiction where OSHA is involved.

\section{A. Statutory Language}

In enacting OSHA, Congress sought both to improve working conditions (by ensuring that certain minimum standards would be met and that enforcement efforts would be undertaken) and to allow the states inaximum flexibility to develop innovative plans to meet local conditions. The text and the legislative history of several sections of the Act reflect these purposes. Thus, while the legislative history does not indicate that Congress explicitly considered state court actions for injunctive relief, the Act does reveal a congressional imtent to allow the states to continue to exercise their authority concurrently with federal authority. Section 2(b)(11), for exainple, encourages "the states to assume the fullest responsibility for the adininistration and enforcement of their occupational safety and health laws ... [and to] improve the administration and enforcement of State occupational safety and health laws . . . ."84

Section 4(b) (4) provides more specifically that:

Nothing in this Chapter shall be construed to supersede or in any inanner affect any workmen's compensation law or to enlarge or diminish or affect in any other manner the common law or statutory rights, duties, or liabilities of employers and employees under any law with respect to injuries, diseases, or death of employees arising out of, or in the course of, employment. ${ }^{85}$

83. P. Bator, D. Mishkin, D. Shapro \& H. Wechisler, The Federal Courts $\&$ THE FEDERAL SYSTEM 800-06 (2d ed. 1973).

84. OSHA \& 2(b)(11), 29 U.S.C. \& 651(b)(11) (1970).

85. Id. $\S 4(\mathrm{~b}) 4,29$ U.S.C. $\S 653$ (b) (4) (1970) (emphasis added). 
This language sweeps broadly. It encompasses the federal employers' liability act, various laws relating to port and maritime operations, and any state system that deals with occupational hazards. The clear congressional instruction is to lrarmonize OSHA with all other applicable laws. The Act's reference to the "common law" includes the potential for growth and adaptation which lies at the heart of the common law process ${ }^{86}$ and can be construed, as one court has done, to permit the enforcement of common law rights in directions compatible with the legislative purpose of OSHA. ${ }^{87}$

OSHA recognizes that the employer is bound by the common law duty to provide a safe and healthful working environment. ${ }^{88}$ Both the Senate and House Committees intended that the Act broaden rather than weaken the duty to provide a safe working environment. ${ }^{89}$ Thus, the primary purpose of the general duty clause is to create a federally

86. For an analogous analysis of the capacity of the common law to adapt to new conditions, see Blumrosen, Common Law Limitations on Employer Anti-union Conduct, 54 Nw. U.L. Rev. 1 (1959), and the discussion at note 87 infra.

87. In Buhler v. Marriott Hotels, Inc., 3 OSHC 1199 (E.D. La. 1974), the court held that the plaintiff may use OSHA standards and evidence that they have been violated as evidence of negligence at trial, to the extent that they would be admissible for that purpose under the rules of evidence. However, in Otto v. Specialties, Inc., 2 OSHA 1424 (D. Miss. 1974), the district court concluded that the Mississippi state courts would not have accepted such evidence because the state court would have construed the congressional policy embodied in section 4(b)(4) as precluding any use of OSHA-related matter in state tort proceedings. The conclusion in Otto is contrary to generally accepted concepts that the law of tort may embody and reflect basic social values, which themselves may find expression in new statutory policies. See Blumrosen, The Right to Seek Workmen's Compensation, 15 RuTGers L. Rev. 491 (1961); Green, Tort Law: Public Law in Disguise, 38 TeXAs L. Rev. 1, 257 (1959); Peck, Judicial Creativity and State Labor Law, 40 Wash. L. REv. 743 (1965); Pound, Common Law and Legislation, 21 HARv. L. Rev. 383 (1908); Stone, The Common Law in the United States, 50 HARv. L. Rev. 4, 12-13 (1936). At least two state courts have modified the common law rule that the employer was free to discharge "at will" in absence of a specific contractual relation, where the evidence showed that the discharge was for a reason that contravened public policy. Frampton v. Central Indiana Gas Co., 260 Ind. 249, 297 N.E.2d 425 (1973); Monge v. Beebe Rubber Co., 114 N.H. 130, 316 A.2d 549 (1974). But see Martinez v. Behring's Bearings Service, Inc., 501 F.2d 104 (5th Cir. 1974).

88. OSHA $\S 5(\mathrm{a}), 29$ U.S.C. $\S 654$ (a) (1970). See text at note 11, supra. Also consider H.R. REP. No. 1291, 91st Cong., 2d Sess. 21 (1970): "The Committee believes that employers are equally bound by this general and common duty to bring no adverse effects to the life and health of their employees throughout the course of their employment. Employers have primary control of the work environment and should insure that it is safe and healthful." There is identical language in S. REP. No. 1282, 91st Cong., 2d Sess. 9 (1970).

89. S. ReP. No. 1282, 91st Cong., 2d Sess. 1 (1970): "The purpose of S. 2193 is to reduce the number and severity of work-related injuries and illnesses which, despite current efforts of employers and government, are resulting in ever-increasing human misery and economic loss." Nearly identical language may be found in H.R. REP. No. 1291, 91st Cong., 2d Sess. 14 (1970). See Miller, supra note 50; Morey, The General Duty Clause of the Occupational Safety and Health Act of 1970, 86 HARv. L. REv. 988 (1973). 
enforceable standard of care in cases where one does not now exist. ${ }^{00}$ By giving the Secretary of Labor the power to enforce obligations which, in the absence of the clause, would flow solely from state law, the general duty clause reaffirms the common law obligation specifically preserved by section 4(b)(4).

Section 18(a), which deals with state plans, must be read in light of section 4(b)(4). It provides: "Nothing in this chapter shall prevent any state agency or court from asserting jurisdiction over any occupational safety or health issue with respect to which no standard is in effect under Section 655 of this title."11 This provision preserves the state administrative and judicial jurisdiction to deal with occupational health and safety problems when no federal standard has been promulgated. Thus, the equitable proceeding suggested in this Article is expressly recognized in those areas.

Section 18(b) is concerned with those areas of occupational safety and health in which standards have been promulgated by the Secretary of Labor. ${ }^{92}$ Nothing in that section restricts the common law cause of action recognized in Section 4(b)(4) and confirmed by the pohicy stated in Section 2(b)(11). Section 18(b) permits the state administrative apparatus under certain circumstances to assert concurrent or even primary jurisdiction over a matter in which a federal standard has been promulgated. These circumstances, described in Section 18(c), ${ }^{93}$ occur when the state standards and state enforcement efforts are "at least as effective in providing safe and healthful employment and places of employment as the standards promulgated under Section 655 of this title which relate to the same issues . . . ."94

In short, Congress sought to establish both a minimum federal level of standards and minimum federal involvement in enforcement. It wanted to ensure that, if a state administrative agency were to supersede the Department of Labor's enforcement powers, it would be "at least as effective" as the federal effort would be. ${ }^{05}$ Congress also recognized that compelling local conditions might require that a different and higher standard be imposed by the states. Both the Senate and House

90. H.R. ReP. No. 1291, 91st Cong., 2d Sess. 21-22, (1970); S. REP. No. 1282, 91st Cong., 2d Sess. 9-10 (1970).

91. OSHA \& 18(a), 29 U.S.C. $\$ 667$ (a) (1970) (emphasis added).

92. Id. \& 6,29 U.S.C. $\$ 655(1970)$.

93. Id. $\$ 18(\mathrm{c})(2), 29$ U.S.C. $\$ 667(\mathrm{c})(2)(1970)$.

94. Id.

95. This is the implication of OSHA § 18(c)(2), 29 U.S.C. $\$ 667$ (c)(2) (1970), and its acceptance of state plans that promulgate and enforce standards which are at least as effective as federal standards. See also the section-by-section analysis of Senate and House Committee Reports. S. ReP. No. 1282, 91st Cong., 2d Sess. 36, \& 16(c) (2) (1970); H.R. Rep. No. 1291, 91st Cong., 2d Sess. 14 (1970). 
Committees discussed the appalling statistics regarding occupational health and safety and the inadequate efforts of the states to remedy the situation. ${ }^{98}$ Criticism was aimed not at strong state action, but at the madequacy of state action. Thus, OSHA sought to increase the support behind existing state government efforts to alleviate health and safety problems by providing funds for innovative state research and for partial funding of state plans. ${ }^{97}$

To ensure that individual state efforts will not continue at the level that made the federal legislation necessary in the first place, section 18 (h) places a 2-year limit on any state standards or enforcement efforts that do not meet the federal minimums. ${ }^{98}$ This section indicates that the Secretary of Labor will not interfere with the power of state courts to act as long as their standards are not more permissive than the federal standards established under section 6 of the Act. ${ }^{99}$

To the extent that the federal safety regulations are inadequate, the state courts may still find a complying employer negligent. The federal regulations can only establish minimum safety standards, which means that where circumstances require additional precautions, mere compliance with the promulgated regulations provides no defense. ${ }^{100}$ Adaptation of this rule to the context of section 18 avoids the potential for conflict between the state and federal regulators. Therefore, the equi-

96. See S. Rep. No. 1282, 91st Cong., 2d Sess. 2-5 (1970); H.R. REP. No. 1291, 91st Cong., 2d Sess. 14-16 (1970).

97. OSHA $\S \S 2$ (b) (11), 23, 29 U.S.C. $\$ \S 651$ (b)(111), 672; S. REP. No. 1282, 91st Cong., 2d Sess. 1, 18 (1970); H.R. Rep. No. 1291, 91st Cong., 2d Sess. 14, 3233 (1970).

98. OSHA $\$ 18(\mathrm{~h}), 29$ U.S.C. $\$ 667(\mathrm{~h})(1970)$ :

The Secretary may enter into an agreement with a State under which the State will be permitted to continue to enforce one or more occupational health and safety standards in effect in such State until final action is taken by the Secretary with respect to a plan submitted by a State under sub-section (b) of this section, or two years from the date of enactment of this Act, whichever is earlier.

See also Letter from Senator Williams to Assistant Labor Secretary George C. Guenther, Noveinber 17, 1972, in which he states that the only purpose of the amendment "was to deal with the time it would take to gear-up federal enforcement capability, and not the time it might take for an individual state plan to be submitted and approved." 2 BNA O.S.H.R. 684 (1972).

99. In Columbus Coated Fabrics v. Industrial Commission of Ohio, 1 OSHC 1361 (S.D. Ohio 1973), the court held that state agencies' actions were preempted by OSHA in situations where a federal standard was in effect and the state had not adopted an approved plan. The decision did not confront the question of an individual action brought in state court to ensure safe working conditions. State court action would be brought by an individual or individuals to vindicate individual rights, unlike state agency action which would vindicate a public right as expressed in a legislative act. Nothing in section 18(b), (c), (29 U.S.C. $\$ 667$ (b), (c) (1970)) or in this decision limits sueh individual actions.

100. See, e.g., C. Morris, ToRTs ch. 4, § 7, at 81-84 (1953); Prosser, supra note 5, at 203-04 (3d ed. 1964); MULER, supra note 50. 
table proceeding suggested in this Article need not create conflict between the federal and state systems. ${ }^{101} \mathrm{~A}$ state court injunction, granted despite the absence of a violation of a federal standard, can be viewed simply as an exercise of state power that is "nnore effective" than the federal law. The Act does not purport to inake the federal standards the inaximum that any jurisdiction can impose on an employer. ${ }^{102}$

Likewise, a request for an injunction, refused by a state court under circumstances where a federal standard is violated, contravenes no federal policy. Injunctive relief may be demed on numerous grounds, such as lack of immediacy or clarity of harm, or because the court believes that the available administrative reinedies are adequate. Such determinations would have no adverse impact on the federal standards. Since the Act does not adopt state court injunctive relief as part of its enforcement inechanism, the failure to grant such relief will not affect the enforceinent of the federal standards. A state court demal of injunctive relief based on a narrow construction of a federal standard or a holding that the standard was invalid would not be bimding on the Secretary of Labor as long as lie was not a party to the litigation. Moreover, it is more likely that the denial would be based on imdependent state grounds rather than on any infirmity in the federal standard.

Thus, the risk of federal-state conflict is remote, whether the state court grants or denies the injunction. This analysis also disposes of the problem of clarity of the division in the state-federal jurisdiction, a factor that is important in basic labor law. The problem does not exist here because there is no right to rely on federal standards on the ground that they set the maximum obligation of the employer.

\section{B. The Labor Law Precedents Permit State Action}

The renaining question is whether the fact that enforcement of OSHA standards rests with the Secretary of Labor forecloses any other authority-state or federal, court or agency-from action. The Act's legislative history contains no explicit analysis and rejection of the notion that judicial proceedings inay be initiated privately to enjoin an occupational hazard. Indeed, section 4(b)(4) recognizes such power in state courts. ${ }^{103}$ This demonstrates a lack of intent to establish the

101. Cf. San Diego Bldg. Trades Council v. Garmon, 359 U.S. 236 (1959); Amalgamated Ass'n of St. Elec. Ry. \& Motor Coach Employees v. Lockridge, 403 U.S. 274 (1971).

102. Contrast the language of section 26 of the Consumer Product Safety Act of 1972, 15 U.S.C. \$ 2051 (Supp. III 1973), which makes the federal standard the minimum standard, and the language of the Air Pollution Control Act, 42 U.S.C. § 1857f6a (1970), which makes federal emission standards for new cars the exclusive standard.

103. See text at note 85 supra. 
Secretary of Labor as the exclusive enforcement arm with respect to matters subject to the statute. ${ }^{104}$

OSHA recognizes that the field of occupational health and safety is complex. The states are encouraged to develop enforcement plans which, if they meet federal minimums, can be adapted to local conditions. Research and development of programs to enhance occupational health safety is encouraged. The statute reflects a desire to improve worker health and safety conditions without supplying the definitive program for achievement of that objective. Under these circumstances, the Act should not be construed to foreclose development of the state common law system.

This conclusion-that occupational hazards should be subject to state enforcement procedures-is consistent with the developed law regarding exclusive federal jurisdiction under the National Labor Relations Act (NLRA).$^{105}$ Under the NLRA, the courts have determined that certain areas of labor-management relations are within the exclusive jurisdiction of the National Labor Relations Board and that state jurisdiction is foreclosed whether the conduct involved is federally protected or prohibited. The Supreme Court has also recognized, however, that in cases involving "interests so deeply rooted in local feeling and responsibility," ${ }^{108}$ Congress could not have meant to foreclose state jurisdiction. State court injunctions and damage awards issued to forestall potentially violent picketing, ${ }^{107}$ to protect worker access to the work place ${ }^{108}$ and to pumish a malicious hibel in a labor dispute have been upheld. ${ }^{100}$

104. Compare this section, with Calhoon v. Harvey, 379 U.S. 134 (1964). There the Supreme Court considered a contention that the "equal rights" provisions of Section 101 (a) (1) of the Labor-Management Reporting \& Disclosure Act of 1959, (29 U.S.C. $\$ \$ 401-531$ (1959)), afforded an adequate basis for a claim that eligibility restrictions upon nomination to national union office were onerous. The Court noted that standards for eligibility were set forth in Title IV of that act, which vested jurisdiction in the Secretary of Labor, and provided an administrative apparatus to review such matters, which was to be "exclusive" as far as post-election review was concerned. It concluded that this structure was intended to be the exclusive method of raising issues arising under Title IV and that therefore Title I rights, which could be enforced in an individual action, were to be construed so as not to overlap with Title IV rights. Congressional treatment of the powers of the Secretary of Labor under Title IV of the LMRDA, compared with his powers under OSHA, makes clear that the thrust toward "exclusivity" in the former act is conspicuous by its absence in the latter. Calhoon provided a formula by which Congress might have made the Secretary's power under OSHA exclusive. It chose not to utilize the formula in enacting OSHA.

105. 29 U.S.C. $\$ \$ 151-187$ (1970).

106. San Diego Bldg. Trades Council v. Garmon, 359 U.S. 236, 244 (1959).

107. Youngdahl v. Rainfair Inc., 355 U.S. 131 (1957).

108. UAW v. Wisconsin Employment Relations Bd., 351 U.S. 266 (1956); UAW v. Russell, 356 U.S. 634 (1958).

109. Linn v. United Plant Guard Workers, 383 U.S. 53 (1966). 
Providing for the physical safety of inhabitants is one of the fundamental purposes of the individual states' general legislative and judicial powers, and worker safety should be recognized as a matter "so deeply rooted in local feeling and responsibility"110 as to resnain within the state jurisdiction under the preemption doctrine. This would probably be so recognized even if OSHA centralized power in the Secretary of Labor to the same extent as the Labor-Management Relations Act (LMRA) ${ }^{111}$ does in the NLRB. So far, however, Congress has neither centralized such power in the Secretary nor created a comprehensive code of safety regulation. Rather, it has carefully preserved state responsibility in the area of worker safety and health.

Congress has also preserved the right of workers to use self-help remedies to protect themselves from work hazards. Section 502 of the Labor Management Relations Act provides that employees who quit work because of abnormally dangerous working conditions shall not be deemed to have gone out on strike. ${ }^{112}$ Similarly, safety is deemed so important that workers are not to be enjomed from striking under section 301 of the LMRA where abnormally dangerous working conditions exist. ${ }^{113}$ Having preserved self-help remedies for workers in connection with safety matters under the LMRA, Congress should not be presumed to have foreclosed these same workers from judicially enforcing their right to a safe and healthful working environment under OSHA. ${ }^{114}$

110. San Diego Bldg Trades Council v. Garmon, 359 U.S. 236, 244 (1959).

111. 29 U.S.C. $\$ \S 141-67,171-97$ (1970).

112. 29 U.S.C. $\$ 143$ (1970). See generally Atleson, supra note 51.

113. Cf. Philadelphia Marine Trade Association v. NLRB, 330 F.2d 492 (3d Cir. 1964), where the court upheld the Board's determination that the refusal to work resulted from abnornally dangerous working conditions and therefore was not a strike under section 502 of the LRA. NLRB v. Knight Morley Corp., 251 F.2d 753 (6th Cir. 1957), cert. denied, 357 U.S. 927 (1958). In that case, the court found that the failure of exhaust fans to operate caused an accumulation of dust, grit and dangerous abrasives, as well as excessive heat and humidity, that could reasonably be interpreted as creating an abnornally dangerous condition.

114. Cf. NLRB v. Washington Aluminum, 370 U.S. 9 (1961). The Supreme Court upheld the Board's deternination that a walkout to protest inadequate heat in a working place was protected activity under section 7 of the NLRA. The Court recognized that one of the purposes of modern federal labor legislation is to correct conditions such as those that existed in this plant. Id. at 17. See Hanna Mining Co. v. United Steelworkers, 464 F.2d 565 (8th Cir. 1972). As in Gateway Coal Co. v. United Mine Workers, 414 U.S. 368 (1974), the court found that the parties had agreed that safety disputes were to be resolved through arbitration. Before issuing an injunction against the strike the court designed its order to eliminate the safety hazard at least until the issue was litigated. Id. at 569. More importantly, the court recognized that although the agreement provided for a mechanism to resolve safety and health disputes, federal and state authorities were not relieved of their obligation to provide a safe place to work. Id. at 568. This obligation also exists when workers try to enforce their rights through 
Finally, the Supreme Court has recognized that national regulation of safety and health is not meant to preclude other methods of regulation. In Gateway Coal Co. v. UMW, for example, the Court held that the comprehensive federal regulation of safety and health in the coal mining industry does not preempt the field to the exclusion of judicially enforceable collectively bargamed arbitration provisions. ${ }^{115}$ The Court found that disputes involving safety issues could be resolved through arbitration if the collective contract had covered the issue and upheld the decision of the district court which, in exercising its equitable power, had suspended the assistant foremen who were the crux of the safety issue. 110 Since OSHA, passed 1 year after the Federal Coal Mine Health and Safety Act of $1969,{ }^{117}$ arose out of the same concerns and has the same basic structure as that act, a similar Court holding should be anticipated when construing OSHA.

\section{VI}

\section{The Common LaW and Arbitration}

Collective bargaining contracts contain a wide variety of terms concerning arbitration and occupational health. Some contain no arbitration clause, others contain clauses explicitly excluding health and safety issues from arbitration, and others contain broad arbitration clauses that empower arbitrators to decide "any and all disputes which may arise between the parties." Usually, arbitration clauses give arbitrators power to decide "all disputes concerning the application or interpretation of the contract." Similarly, the health and safety clauses range from adopting the standards of the OSH Administration to merely hortatory safety clauses. ${ }^{118}$ This range of possible contract terms necessarily affect the ways in which a collective contract arbitration may affect an individual's right to injunctive rehef against occupational hazards.

\section{A. Existence of a Collective Bargaining Contract Does Not Foreclose Equity Court Action}

The American labor policy favoring arbitration is expressed in the Steelworkers Trilogy and its progeny. ${ }^{119}$ The Trilogy, which is founded

strike action. It encompasses the court's responsibility to provide equitable relief to alleviate unsafe working conditions. See Atleson, supra note 51.

115. Gateway Coal Co. v. Umited Mine Workers, 414 U.S. 368, 380 n.10 (1974).

116. Id. at 387 .

117. 30 U.S.C. $\$ \$ 801-960$.

118. BNA survey of contract clauses. See, e.g., Bureau of National Affairs, Inc., Analysis of Safety and Health Provisions in 1973 Collective Bargaining Contracts, 4 BNA OCC. SAFETX AND HEALTH REP. 1206 (February 6, 1975).

119. The Steelworker Trilogy: United Steelworkers v. American Mfg. Co., 363 
on section 301(a) of the LMRA, ${ }^{120}$ encourages arbitration by giving the widest possible interpretation to any arbitration clause in a labor contract ${ }^{121}$ and by restricting the scope of judicial review of an arbitration award. ${ }^{122}$ Rights to safe working conditions under collective agreements inay overlap with the state-created right discussed here, even though the latter rights have their origin in state tort law rather than in the collective contract.

In two recent cases the Supreme Court considered situations where a collective agreement with arbitration procedures dealt with matters also regulated by general law. In both cases the Court rejected the argument that the existence of arbitration clauses in a collective bargaining agreement precluded use of a forum to enforce general law. Thus, in Gateway Coal Co. v. UMW, ${ }^{123}$ the Court upheld a district court anti-strike injunction conditioned on elimination of a safety dispute pending arbitration. The dissent argued that the Coal Mine Safety Administration's jurisdiction was exclusive and precluded arbitration. In rejecting that argument, the majority acknowleclged that the two forums shared concurrent jurisdiction. ${ }^{124}$ Under the decision, workers have the right to seek relief both from the Coal Mine Safety Administration and through arbitration under a collective agreement.

Similarly, in Alexander v. Gardner-Denver Co., ${ }^{125}$ a case involving the interaction of Title VII of the Civil Rights Act of $1964^{126}$ with the policy favoring arbitration, the Court stated: "[t]he distinctly separate nature of these contractual and statutory rights is not vitiated merely because both were violated as a result of the same factual occurrence.

U.S. 564 (1960); United Steelworkers v. Warrior \& Gulf Navigation Co., 363 U.S. 574 (1960); United Steelworkers v. Enterprise Wheel \& Car Corp., 363 U.S. 593 (1960).

The "industrial peace" rationale is consistently referred to as the principal aim of arbitration. Section 203(d) of the LMRA, 29 U.S.C. $\$ 173$ (d) (1970) states: "[f]inal adjustment by a method agreed upon by the parties is hereby declared to be the desirable method for settlement of grievance disputes arising over the application or interpretation of an existing collective-bargaining agreement. . .." Cf. Teamsters Local $174 \mathrm{v}$. Lucas Flour Co., 369 U.S. 95, 105 (1962); United Steelworkers v. Warrior \& Gulf Navigation Co., 363 U.S. 574, 578 (1960); Textile Workers Union v. Lincoln Mills, 353 U.S. 448, 454-55 (1957); S. REP. No. 105, 80th Cong., 1st Sess. 16-18 (1947).

120. 29 U.S.C. $\& 185$ (a) (1970). This section provides, in pertinent part, that: "[s]uits for violation of contracts between an employer and a labor organization representing employees in an industry affecting commerce . . . may be brought in any district court. ..."

121. Umited Steelworkers v. Warrior \& Gulf Navigation Co., 363 U.S. 574, 582-85 (1960).

122. United Steelworkers v. Enterprise Wheel \& Car Corp., 363 U.S. 593, 596-99

(1960); United Steelworkers v. American Mfg. Co., 363 U.S. 564, 568 (1960).

123. 414 U.S. 368 (1974).

124. Id. at 380 n. 10.

125. 415 U.S. 36 (1974).

126. 42 U.S.C. $\$ \$ 2000 \mathrm{e}$ to $2000 \mathrm{e}-17$ (1972). 
And certainly no inconsistency results from permitting both rights to be enforced in their respectively appropriate forums."127 The Court found Alexander's rights constituted "an individual's right(s)" and were therefore based on a ground distinct from collective rights in the majoritarian bargaining process. ${ }^{128}$

Both cases imdicate that the existence of a collective bargaining agreement that provides for arbitration does not foreclose consideration in a different tribunal of separate claims arising from the same facts. Moreover, the limits on judicial intervention into arbitration only apply when a court exercises jurisdiction under section 301(a) of the LMRA $^{129}$ to review a contract claim. If a court has jurisdiction under a statute other than section 301 , the arbitrators have less autonomy.

\section{B. Chancellors' Discretion to Abstain Pending Arbitration}

Despite the separate legal nature of arbitration and its obvious lack of equivalence with the judicial process, ${ }^{130}$ employers may ask equity courts to refrain from ruling on an application for an injunction against occupational hazards pending arbitration. Such absention may be dangerous to the worker where the threatened danger is imminent or the arbitration is likely to be slow.

To secure a preliminary injunction, the employees must demonstrate a great likelihood of irreparable injury from an unabated occupational hazard..$^{131}$ If they cannot, the court will probably stay the action pending arbitration. For example, if an improperly shored excavation threatens to collapse and possibly kill some workers, delay by the chancellor pending arbitration could be deadly. In contrast, to delay a suit to abate noise from industrial machinery pending arbitration entails only the risk that the workers involved will suffer continued loss of hearing for that period of time. In such cases, even though the court will probably be reluctant to grant the requested injunction, the court

127. Id. at 50 .

128. In contrast to OSHA, Title VII of the Civil Rights Act of 1964 provides the individual with a statutory cause of action against an employer for violation of its provisions. 42 U.S.C. $\$ 2000$ e-5(f)(1) (1970). However, the Court did not rely on this statutory basis, but rather on the inferred intent of Congress that Title VII was designed to supplement the existing remedies to employment discrimination, in finding the cause of action not precluded by prior arbitration. An analogous inference as to congressional intent to expand remedies for enforcement of occupational safety would support a state cause of action subsequent to arbitration on that subject.

129. 29 U.S.C. $\$ 185$ (a) (1970).

130. In U.S. Bulk Carriers, Inc. v. Arguelles, 400 U.S. 351, 359-60 (1971), Justice Harlan, concurring, stated that "the choice of forums imevitably affects the scope of the substantive right to be vindicated before the chosen forum." Accord, Alexander v. Gardner-Denver Co., 415 U.S. 36, 56-58 (1974).

131. See text accompanying notes 52-55 supra. 
should compel prompt arbitration by requiring the parties to return to court on a specific date to review the arbitration award. ${ }^{132}$

It is impossible for the courts to estimate the extent to which an arbitrator will modify a collective bargaining agreement to conform with his or her view of public policy. There is a lack of consensus on this issue within the arbitration profession itself. A broad view of an arbitrator's power to read public law into collective labor contracts was recently approved in an arbitration case where Title VII of the Civil Rights Act of 1964 was applied to a contract containing no Title VII language. ${ }^{133}$ In response to the company's argument that the arbitrator exceeded its contractual authority, the court answered "[i]t is basic contract law that valid applicable statutory provisions are parts of every contract . . .."134 In contrast, the view that the arbitrator is limited to the private agreement was accepted by the Supreme Court in United Steelworkers of America v. Enterprise Wheel and Car Corp. ${ }^{135}$ Justice Douglas, writing for the majority, stated, "[the award] may be read as based solely upon the arbitrator's view of the requirements of enacted legislation, whicl would mean that he exceeded the scope of the submission."136 As a result of this opinion, many arbitrators conclude that they may not incorporate public policy considerations in their decisions. ${ }^{137}$ For this reason, courts should be even less inclined to rely on the arbitration process to vindicate the federal policy aimed at preventing occupational hazards.

132. Another aspect of the relation of courts and arbitration is raised by the NLRB policy expressed in Spielberg Mfg. Co., 112 NLRB 1080, 36 LRRM 1152 (1955), and Collyer insulated Wire, 192 NLRB 837, 77 LRRM 1931 (1971), in which the Board deferred to arbitration in cases where unfair labor practice charges are also cognizable as contract disputes. Any suggested analogy to the case considered here misses a inajor difference between the NLRB and OSH enforcement program.

This NLRB policy is predicated on the fact that a well-developed body of law is available for arbitrators to use to interpret clauses in collective contracts to implement the policy of the NLRA. In contrast, OSHA law is new and undeveloped. Arbitrators have much less guidance in this area. At this early time in the life of the OSHA, if the OSH Administration were to develop a policy of deferral analogous to the NLRB, it would be yielding policymaking powers to arbitrators who have no reason or basis to assume them. For an illustration of a comparable situation in which the NLRB concluded that an arbitrator under a collective agreement could reform a discriminatory seniority system, see A. BLUMROSEN, BLACK EMPLOYMENT AND THE LAW ch. 4 (1971). The arbitrator declined to accept his conimission from the Board.

133. Goodyear Tire and Rubber Co. v. Rubber Workers Local 200, 8 FEP 128 (Ohio Ct. App. 1974).

134. Id. at 131. See generally Elkouri \& Elkouri, How Arbirration Works ch. 10 (3d ed. 1973).

135. United Steelworkers v. Enterprise Wheel \& Car Co., 363 U.S. 593 (1960).

136. Id. at 597.

137. Note, The Authority and Obligation of a Labor Arbitrator to Modify or Eliminate a Provision of a Collective Bargaining Agreement Because in His Opinion It Vio. lates Federal Law, 37 Oнпо ST. L.J. 395 (1971). 


\section{Arbitration Awards as Evidence in Actions for Injunctive Relief}

In the Gardner-Denver case, ${ }^{138}$ the Supreme Court analyzed the degree of finality to be accorded an arbitral award under a collective agreement dealing with the same facts as a suit based on a legal duty. The Court held that an individual employee's statutory right to a trial on a Title VII claim is not precluded by the final judgment of an arbitrator under the nondiscrimination clause of a collective bargaining agreement. The Court held that arbitral awards are not binding on the district courts, but that they should be admissible as evidence. Since there is no material distinction between the finality issues in Gardner-Denver and those to be faced by a chancellor in an occupational hazard case, the same rule is applicable: arbitral awards should be admissible as evidence before the court both on the facts and on the determination of whether a hazard exists.

\section{CONCLUSION}

In enacting OSHA, Congress recognized the right to work under safe conditions and conferred on administrators the authority to protect this right by implementing the Act. Neither this grant of authority nor preexisting federal law foreclosed state action in the area of occupational safety, however. Therefore, workers faced with continuing occupational hazards may seek injunctive relief froin state courts, provided they can establisl their right to such relief under general equitable principles of state law. An action to enjoin a continuing occupational hazard fits comfortably within these principles. If workers can demonstrate the futility of recourse to administrative or collective bargaining remedies, they are entitled to injunctive relief.

The availability of this rehef should spur those who adininister the network of safety legislation at the state or federal level to provide a more effective enforcement apparatus than presently exists. The individual cause of action may become the energizing factor to secure more effective overall implementation of OSHA. But even if this hope proves too optimistic, the injunction against occupational hazard is itself an important development in tort law. It protects, in a nodern setting, the long-recognized imterest in plyysical safety. As productive processes become increasingly complex and more carefully organized and planned, the opportunity for prevention of injuries is increased. Now that Congress has required the employer to plan for the safety of workers, tort law nuay protect the right to work under safe conditions where the administrative apparatus is not effective.

138. 415 U.S. 36 (1974). 